\title{
Reproductive Health Education in the Elderly
}

\author{
Yuli Mulyanti ${ }^{1}$,Deswani
}

\author{
Nurse Department Polytechnic Ministry of Health, Jakarta III \\ Jalan Arteri Jorr Jatiwarna Pondok Mealti Bekasi Indonesia \\ Email: yulimulyanti01 [AT] gmail.com
}

\begin{abstract}
An understanding of reproductive health in the elderly, especially women, becomes so important because there are so many changes that occur when women enter old age. Decreasing reproductive health in women occurs when women enter menopause. For this reason, it is necessary to provide appropriate information to the elderly regarding the health of their reproductive system, to avoid health problems that threaten the overall condition of the body. This study aims to determine the effect of reproductive health education in the elderly. The research method used was quasi-experimental with non-randomized pretest-posttest group control design. The number of samples in this study was 62 people consisting of 32 people in the intervention group and 30 people in the control group. Data analysis in this study with paired t-test and independent. The results showed that there was a significant difference in knowledge of the elderly between the intervention group and the control group after the intervention (pvalue $=0,000$ ), so there were significant differences in the attitudes of Keywords: reproductive health education, elderly, knowledge, attitudes the elderly between the intervention and control groups, after the intervention $(p=$ 0.008). The conclusion is that there is an influence of reproductive health education in the elderly on the knowledge and attitudes.
\end{abstract}

Keywords - reproductive health, elderly, knowledge, attidtudes

\section{INTRODUCTION}

Indonesia's population in 2017 was 23.4 million or $8.97 \%$ of all Indonesia was elderly. Therefore, Indonesia belongs to an aging population, because the elderly population over the age of $60-69$ years is above $5,65 \% .{ }^{1}$ It is estimated that this number will likely continue to increase every year so that it will also be followed by increasing problems in the elderly.

According to the workforce survey, the elderly who are still actively working to fulfill their daily needs is $47.92 \% .^{2}$ But it is known that the more the age grows, the elderly will experience a decline in organ function so that there will be more morbidity in the elderly. Elderly morbidity rates in 2014 amounted to 25.05 meaning that of 4 elderly people, one person had experienced pain. ${ }^{3}$

Reproductive health is a healthy condition as a whole, covering physical, mental, social aspects, and not only free from diseases related to the reproductive system and its functions. Reproductive health not only addresses the issue of pregnancy or childbirth but covers the entire life cycle of women, one of which is menopause, which is a period that begins at the end of the reproductive period and ends in the medium (age), namely at the age of 40-65 years. ${ }^{4}$

The earlier the menarche occurs the slower the menopause occurs. but sometimes it can occur faster or slower, depending on the reproductive health of the woman. Also, general physical health factors, heredity, and lifestyle also affect when a woman will experience menopause. The menopausal phase usually causes many complaints and disorders, not only on reproductive health but also general health. For this reason, elderly reproductive health must get attention.

The age of menopause in Indonesian women averages 49 years. The earlier the menarche occurs the slower the menopause occurs. but sometimes it can occur faster or slower, depending on the reproductive health of the woman. Also, general physical health factors, heredity, and lifestyle also affect when a woman will experience menopause. The age of menopause in Indonesian women averages 49 years. The menopausal phase usually causes many complaints and disorders, not only on reproductive health but also general health. For this reason, elderly reproductive health must get attention.

An understanding of reproductive health in the elderly, especially women, becomes so important because there are so many changes that occur when women enter old age. The decline in reproductive health in older men usually occurs when men enter the stage of andropause, namely the decline in reproductive function. While a decline in reproductive health in women occurs when women enter menopause. 
In elderly women, menopause is a sign that fertility has dropped dramatically, marked by the cessation of menstruation for at least one year. Before the menopause phase begins, reproductive health begins to decline about four or five years before, where women usually have begun to feel some physical symptoms. Although different forms, physical symptoms before menopause must be considered so that reproductive health is also maintained.

The symptoms of menopause can affect physical health and reproductive health. Physical disturbances include heat in the chest that rises to the face and occurs at night (hot flush). While the decline in the reproductive health of elderly women is felt when experiencing urinary tract disorders, infections of the urinary tract, pain when copulating because the vagina no longer produces lubricating fluids. In addition to decreased reproductive health, the functions of other organs also decrease, including reduced production of tears, causing eye disorders and also the emergence of psychological disorders such as irritability, anxiety, and loss of sexual arousal. Health problems that arise during menopause are bone and joint pain, pain during intercourse, dementia, the incidence of malignancy (prostate, cervix, mommy), coronary heart disease, and impotence. ${ }^{4}$

Elderly Reproductive Health is more emphasized to improve the quality of life in the elderly. Advanced reproductive health efforts are also aimed at addressing problems that are often found in the elderly, such as menopause/andropause, osteoporosis, prostate cancer, and other diseases that can affect the reproductive organs.

Certain physical and psychological changes are seen in old age, both men and women in old age will adjust themselves, but the results obtained from these adjustments tend to lead to and bring about unfavorable self-adjustment mainly due to the physical and mental deterioration that takes place gradually.

Being elderly is that cannot be avoided, with increasing age changes that occur physically and psychologically. Changes in the structure and function of cells and the tissues and organs of the body affect health. Likewise with body functions related to reproductive health. Menopause is one sign that there has been a change in women's reproductive function. Some women undergo menopause as natural and without complaints but are aware or not experiencing physical and psychological changes that can affect the quality of life for older women

Based on the description above, and one of them is a lack of information, it is likely to pose a dangerous health risk. Therefore, this study aims to prove whether there is an influence on the education of elderly reproductive health on knowledge and attitudes.

\section{METHODS}

All The type of research used was quasi-experimental research with a non-randomized pretest-posttest group control design. The study was conducted by providing reproductive health education interventions for elderly women in the intervention group and comparing the results of interventions with groups without intervention or control groups.

This research was conducted in Cipayung Region, East Jakarta. The population in this study were all elderly women, while the study sample consisted of 62 people, 32 intervention groups and 30 control groups. This study has obtained ethical clearance from Health Polytechnic Jakarta III, Indonesia.

This research uses a data collection tool in the form of questionnaires. Data collection in the intervention group was carried out three times. At the first meeting, the researcher conducted a pre-test on the subject of the study, then provided the reproductive health material for the elderly. At the second meeting, which was 3 days after the first meeting the researchers provided education and discussion to the research subjects. The third meeting of the researchers gave a posttest to the research subject. While the control group was given a pre-test and a week later the post-test was untreated. Data analysis in the study was using paired t-test

\section{RESULTS}

The characteristics of the elderly from the intervention and control groups were almost the same, the majority of the pre-elderly age, 45-59 years, were Muslim, came from the Javanese tribe and the majority were high school education. Most people suffer from the same disease like hypertension, most have no menstruation and most of the last menstruation at the age of less than or equal to 50 years $(66.7 \%)$ 
Table 1. Distribution of characteristics of the elderly based on age, sex, and education

\begin{tabular}{|c|c|c|c|c|c|c|}
\hline \multirow[t]{2}{*}{ Variabel } & \multicolumn{2}{|c|}{$\begin{array}{l}\text { Intervention } \\
\text { group }\end{array}$} & \multicolumn{2}{|c|}{ Control group } & \multicolumn{2}{|c|}{ Total } \\
\hline & $\mathrm{N}$ & $\%$ & $\mathrm{~N}$ & $\%$ & $\mathrm{~N}$ & $\%$ \\
\hline \multicolumn{7}{|l|}{ Age of elderly } \\
\hline $\begin{array}{l}\text { 1. Pra elderly } \\
\text { (45-59 years })\end{array}$ & 20 & 71,4 & 16 & 53,3 & 36 & 60 \\
\hline $\begin{array}{l}\text { 2. Elderly } \\
(>60 \text { years })\end{array}$ & 12 & 28,6 & 14 & 46,7 & 26 & 40 \\
\hline \multicolumn{7}{|l|}{ Religion } \\
\hline 1. Islam & 29 & 90 & 26 & 86,7 & 53 & 88,3 \\
\hline 2. Christian & 3 & 10 & 3 & 10,0 & 6 & 10 \\
\hline 3. Hinduism & 0 & 0 & 1 & 3,3 & 3,3 & 2,7 \\
\hline \multicolumn{7}{|l|}{ Ethnic } \\
\hline 1.Jawa & 16 & 53,3 & 10 & 33,3 & 26 & 43,3 \\
\hline 2. Non Jawa & 14 & 46,7 & 20 & 66,7 & 34 & 56,7 \\
\hline \multicolumn{7}{|l|}{ Education } \\
\hline 1.Primary school & 4 & 13,3 & 14 & 46,7 & 18 & 30 \\
\hline 2. Yunior School & 8 & 26,7 & 7 & 23,3 & 15 & 25 \\
\hline 3. High school & 17 & 56,7 & 8 & 26,7 & 25 & 41,7 \\
\hline 4. Academy & 1 & 3,3 & 1 & 3,3 & 2 & 3,3 \\
\hline
\end{tabular}

Table 2.Distribution of Characteristics of the Elderly Based on the Type of Disease and Last Menstruation

\begin{tabular}{lcccccc}
\hline Variabel & \multicolumn{2}{c}{ Intervention Group } & \multicolumn{2}{c}{.Kontrol group } & \multicolumn{2}{c}{ Total } \\
\cline { 2 - 7 } & $\mathrm{N}$ & $\%$ & $\mathrm{~N}$ & $\%$ & $\mathrm{~N}$ & $\%$ \\
\hline & 4 & 13,3 & 27 & 90 & 31 & 51,7 \\
1. Hipertention & 4 & 13,3 & 0 & 0 & 4 & 6,7 \\
2. Diabetes Mellitus & 4 & 13,3 & 3 & 10 & 7 & 11,6 \\
3. Knee pain & 1 & 3,3 & 0 & 0 & 1 & 1,7 \\
4. Osteoporosis & 3 & 10 & 0 & 0 & 3 & 5 \\
5. Others & 14 & & 0 & 0 & 14 & 23,3 \\
6. Not sickness & & & & & & \\
Still mesntruation & 5 & 16,7 & 6 & 20 & 11 & 18,3 \\
1. Yes & 25 & 83,3 & 24 & 80 & 49 & 81,7 \\
2. No & & & & & &
\end{tabular}

Age at Last Menstruation

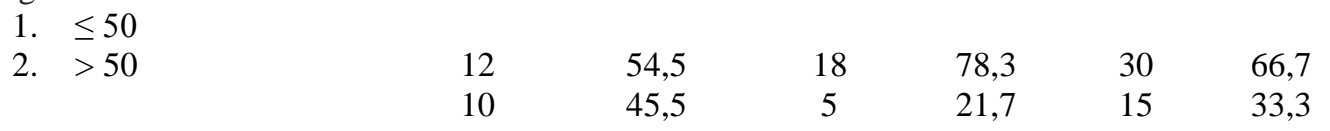

Table 2. above shows that the characteristics of the elderly in the two groups are almost the same, namely having the type of disease suffered by hypertension, most of them have no menstruation and most of the last menstruation at the age of less than or equal to 50 years $(66.7 \%)$.

Differences in knowledge and attitudes before and after group intervention in the intervention and control groups 
Table 3. Analysis of Knowledge and Attitudes Before and After Group inter-Group Iintervention

\begin{tabular}{llllll}
\hline Variabel & \multicolumn{1}{c}{ Group } & N & Mean & SD & P value \\
\hline Knowledge & Intervention & & & & \\
& Before & 32 & 9,13 & 2,060 & 0,018 \\
& After & 32 & 9,97 & 1,204 & \\
& Difference & & 0,84 & & \\
\cline { 2 - 5 } & Controle & & & & \\
& Before & 30 & 9,00 & 1,083 & $\mathbf{0 , 0 3 7}$ \\
& After & 30 & 9,70 & 1,022 & \\
& Difference & & 0,7 & & \\
\hline Attitude & Intervention & & & & \\
& Before & 32 & 41,03 & 4,139 & $\mathbf{0 , 3 9 7}$ \\
& After & 32 & 41,56 & 3,369 & \\
& Difference & & 0,53 & & \\
\cline { 2 - 6 } & Controle & & & & \\
& Before & 30 & 38,97 & 4,390 & $\mathbf{0 , 4 0 9}$ \\
& After & 30 & 38,47 & 5,335 & \\
& Difference & & $-0,5$ & & \\
\hline
\end{tabular}

The results of the analysis showed that there were significant differences in knowledge before and after the intervention in the intervention group and the control group before and after the intervention (values $\mathrm{p}=0.018$ and 0.037 ) with the difference in mean values greater in the intervention group compared to the control group. While attitudes showed no significant differences in both the intervention group and the control group with $\mathrm{p}>0.05$.

Differences in knowledge and attitudes of the elderly after the inter-group intervention

Table 4. Analysis of knowledge and attitudes after intervention between groups

\begin{tabular}{llcccccc}
\hline \multicolumn{1}{c}{ Variable } & \multicolumn{1}{c}{ Group } & $\mathrm{N}$ & Mean & SD & $95 \%$ CI & F & P value \\
\hline Knowledge & Intervention & 32 & 9,97 & 1,204 & $0,699-1,838$ & 0,279 & $\mathbf{0 , 0 0 0}$ \\
& Control & 30 & 8,70 & 1,022 & $0,702-1,835$ & & 0,008 \\
\hline Attitude & Intervention & 32 & 41,56 & 3,369 & $0,844-5,348$ & 1,984 & $0,801-5,391$ \\
& Control & 30 & 38,47 & 5,335 & 0,801 & & \\
\hline
\end{tabular}

The results of the analysis showed that there was a significant difference in knowledge of the elderly between the intervention group and the control group after the intervention ( $p$-value $=0,000)$, as well as significant differences in the attitudes of the elderly between the intervention and control groups, after the intervention ( $\mathrm{p}$-value $=0.008$ )

\section{DISCUSSION}

The results showed that the intervention and control groups had almost the same characteristics, the majority were pre-elderly, 45-59 years old, were Muslim, came from Javanese and the majority were high school education. Preelderly age is also classified as middle age.

Hurlock, limiting middle age is around 40 - 60 years. He divided 2 phases, namely early middle age (40-50 years) and advanced middle age (50 -60 years). ${ }^{5}$ According to Erikson's developmental theory, the main developmental task in middle age is achieving generative. ${ }^{6}$ Generative is a mature and broad sense of caring than intimacy because this love has "generalized" to other groups, especially the next generation. If with intimacy we are involved in a relationship where we expect reciprocity from our partners, then with generativity we do not expect a response (the desire to care for and guide others). Middle adults can achieve generativity with their children through guidance in social interaction with the next generation. If middle adults fail to reach generative stagnation will occur. Stagnation is the opposite of generative namely our limited concern for ourselves, no care for others.

Middle age is one of the times in a person's life where many major events occur that force him to reorganize. The rearrangement can occur because of some major changes in physiological, psychological, sexual and social changes that accompany these three changes.

Some characteristics of middle age, the first characteristic of middle age for men and women include fear of entering middle age. There are many unpleasant stereotypes about middle age, namely traditional beliefs about the mental and physical damage that are thought to be accompanied by the cessation of the reproduction of life. 
The second feature at this age is the transition period. The transitional period in which men and women leave physical and behavioral traits of their sexual maturity and enter a period in life which will be covered by new physical and behavioral traits. Therefore, to survive it must make adjustments to the changes that occur.

Other middle age characteristics are times of stress, somatic stress caused by physical changes due to the aging process. Cultural stress is derived from the placement of high values on youth, courage, and success by certain cultural groups. Economic stress, due to family financial burdens, and psychological stress, may be caused by the death of a husband or wife, the departure of a child from home, boredom in marriage, or a sense of loss of youth and nearing the threshold of death.

Most illnesses are hypertension and knee pain, along with the increasing age of health problems that often occur are hypertension, this disease is the third-ranked disease in the elderly. Other physical changes that change in reproduction are marked by the cessation of menstruation. This study found that most of the respondents were no longer menstruating as much as $83.3 \%$. The age at the time of the last menstruation is mostly at the age of less than or equal to 50 years as much as $66.73 \%$. Riskedas 2013, a non-communicable disease that often occurs in the elderly includes stroke, chronic obstructive pulmonary disease and diabetes mellitus. Hypertension is very associated with the disease or it can also be a complication of the disease. ${ }^{7}$

Stopping the menstrual period is a sign that it has entered menopause, a condition that can cause changes in the reproductive organs, among others, is the uterus is atrophy (a state of tissue nutritional deterioration), the length shrinks, and the walls thin. The myometrial tissue (uterine muscle) becomes smaller and contains more fibrotic tissue (excessive filamentous properties). The cervix (cervix) shrinks not protruding into the vagina for a long time and evenly with the vaginal wall.

Before the menopause phase begins, reproductive health begins to decline about four or five years before, where women usually have begun to feel some physical symptoms. Physical symptoms that arise before menopause can vary in shape for each woman, however, women should adapt to these changes and overcome physical complaints that arise, so that reproductive health can be maintained.

The results of the study showed that most respondents had good knowledge about reproductive health. More than $50 \%$ of respondents can answer questions correctly, such as understanding menopause, menopausal symptoms, changes that occur at menopause and activities that must be done to stay healthy. There were significant differences in knowledge before and after the intervention $(\mathrm{p}=0,037)$. It means that health education is given meaning in increasing knowledge.

There was a significant difference in knowledge of the elderly between the intervention group and the control group after the intervention $(p$-value $=0,000)$. In line with the results of Arifah's research, 2010 that health education with modules on women's knowledge and attitudes about menopause. ${ }^{8}$ Likewise, with the results of Ismiyati's research, that there is an influence of health education about menopause with readiness to treat menopause in pre-menopausal mothers. ${ }^{9}$

Knowledge is the result of human sensing or the result of knowing someone to an object through the senses that it has, eyes, nose, ears and so on. By itself, at the time of experience to produce knowledge is greatly influenced by the intensity of attention and perception of the object. Most of a person's knowledge is obtained through the hearing (ear), and senses of sight (eyes). A person's knowledge of objects has a different intensity or level. ${ }^{10}$

Health education is part of health promotion, namely a process to improve people's ability to maintain and improve their health by not only linking themselves to improving knowledge, attitudes and practices, but also improving and improving the environment (both physical and physical) in order to maintain and improve health. ${ }^{10}$

Attitude is a person's closed response to a particular stimulus or object, which has involved the factors of opinion and emotion concerned (happy to be unhappy, agree disagree, not good, etc.). ${ }^{10}$ Attitude is a syndrome or collection of symptoms in response to stimulus or object so that the attitude involves other thoughts, feelings, attention, and psychological symptoms.

In this study, there was no significant difference between the intervention group and the control group with $p>$ 0.05. This means that both the intervention group and the control group have a balanced attitude. However, the results of the post-test showed that there were significant differences in the attitudes of the elderly between the intervention group and the control group, after the intervention $(\mathrm{p}=0.008)$. The results of Arifah's research, it was found that there was an effect of health education on women's knowledge and attitudes about menopause. ${ }^{8}$ Result M Rotem, it was found Participation in a program that combines delivery of information and processing of experiences on the cognitive, emotional, and social levels may improve women's attitudes toward menopause and ease the perceived severity of their symptoms, thereby increasing quality of life. ${ }^{11}$

\section{CONCLUSIONS}

The characteristics of the respondents were mostly pre-elderly, 45-59 years old, Muslim, originating from the Javanese tribe and the majority of education was high school. Most suffer from hypertension and the last menstruation at the age of less than or equal to 50 years. 
There was a difference in the level of knowledge of the elderly about reproductive health before and after intervention in the intervention and control groups.

There were no differences in the attitudes of the elderly about reproductive health before and after the intervention of the intervention group and the control group.

There are differences in knowledge and attitudes of the elderly about the reproductive health of the elderly after the intervention between the intervention groups and the control group.

\section{REFERENCES}

[1] Susenas. Badan Pusat Statistik, 2017.

[2] Sakernas, Badan Pusat Statistik, 2017

[3] Infodatin (Pusat Data dan Informasi). Situasi Lanjut Usia di Indonesia. Kementrian Kesehatan RI. Jakarta, 2016

[4] Lowdermilk, Perry \& Cashion, Keperawatan Maternitas. Buku: 2, edisi 8. Jakarta : Salemba Medika, 2013

[5] Hurlock, Psikologi Perkembangan : Suatu Pendekatan Sepanjang Rentang Khidupan. Jakarta: Erlangga, 2011

[6] Erickson H Erik, Tahap perkembangan manusia Psikoseksual dan kepribadian, 2010. www.psichologymania.co.cc/../perkembangan-kepribadian-dan.html.

[7] Rikesdas, 2103.

[8] Arifah, Siti, Pengaruh Pendidikan Kesehatan dengan Modul dan Media Visual terhadap Peningkatan Pengetahuan dan sikap Wanita dalam menghadapi Menopause. Tesis. UNS Surakarta, 2010

[9] Ismiyati, Pengaruh penyuluhan Kesehatan tentang Menopause terhadap Kesiapan menghadapi Menopause pada Ibu pre menopause di dusun Pandes, Bantul, Yogyakarta, 2013.

[10] Notoadmodjo Soekidjo, Promosi Kesehatan dan Ilmu Perilaku, Jakarta : PT Rineka Cipta, 2007.

[11] M Rotem et al. A psicho-ducational Program for Improving Women's Attitude and Copyng with Mneopause Symptom. JOGNN Vol.34. Issue 2, March 2006. http: doi.org/10.1177/0884217504274417. 